\title{
Pemfigusta Risk Faktörleri
}

\section{Risk Factors in Pemphigus}

\section{Gülșen Tükenmez Demirci, Ayșe Tülin Mansur*, İkbal Esen Aydıngöz**}

Bașkent Üniversitesi İstanbul Sağlık Uygulama ve Araștırma Merkezi Hastanesi, Deri ve Zührevi Hastalıklar Kliniği, İstanbul, Türkiye

*Ahu Hetman Hastanesi Deri ve Zührevi Hastalıklar Kliniği, Muğla, Türkiye

**Acıbadem Üniversitesi Tıp Fakültesi, Deri ve Zührevi Hastalıklar Anabilim Dalı, İstanbul, Türkiye

\section{Özet}

Amaç: Pemfigusun ortaya çıkmasında ve hastalığın seyrinde bazı dıș faktörlerin etkili olduğu üzerinde durulmaktadır. Bu araștırmada pemfigus tanıs ile takip ettiğimiz hastalarda hastalığın etyolojisinde rol oynayabilecek faktörlerin araștırılması amaçlanmıștır. Gereç ve yöntem: Kliniğimizde 1998-2004 yılları arasında histopatolojik ve direkt immunofloresan incelemeler ile pemfigus tanısı konan 15'i erkek, 27'si kadın toplam 42 hasta, demografik özellikler, meslek grubu, eğitim düzeyi, hastalığın ortaya çıkmadan önceki süreçte geçirilmiș stresli yașam olayları, gebelik sayısı, diyet, sigara ve alkol alıșkanlığı gibi etkenler açısından sorgulanarak benzer sosyoekonomik düzeye sahip, aynı yaș ve cinsiyetteki bir kontrol grubuyla karșılaștırıldı.

Bulgular: Hayvancılık ve tarım ile uğrașmanın, gebelik sayısının fazla olușunun, sigara içmemenin ve psikolojik stresin pemfiguslu hastalarda kontrol grubuna göre istatistiksel olarak anlamlı oranda yüksek bulunduğu saptandı.

Sonuç: Hayvancılık ve tarım ișlerinde çalıșmanın, çok sayıda gebelik geçirmiș olmanın, sigara içmemenin ve psikolojik stresin pemfigusun etyolojisinde ve seyirinde rol oynayabileceği kanısına varıldı. (Türkderm 2011; 45: 140-5)

Anahtar Kelimeler: Pemfigus, risk faktörleri

\section{Summary}

Background and Design: There have been reports suggesting the involvement of environmental factors in the disease process of pemphigus. In this study, we aimed to find out the risk factors which could play role in the etiopathogenesis in our pemphigus patients. Material and method: A total of 42 patients (15 male and 27 female) who were diagnosed as pemphigus with histopathological and direct immunoflurosence examinations in our clinic between the years 1998-2004, were interviewed for assessment of regarding with the subjects of the demographic properties, occupational groups, educational level, the number of pregnancies, stressfull life events, diet habits, smoking and alcohol consumption before the onset of the disease and the results were compared to 42 age and gender-matched controls with similar socioeconomic circumstances.

Results: Working in agriculture and livestock, multi-parity, absence of smoking and stressfull life events were found to be statistically significant in pemphigus patients than in controls.

Conclusion: Working in agriculture and livestock, multi-parity, absence of smoking and stressfull life events were assumed to play role in the etiopathogenesis and course of pemphigus. (Turkderm 2011; 45: 140-5)

Key Words: Pemphigus, risk factors

\section{Giriş}

Pemfigus deri ve mukozalarda bül oluşumu ile karakterize, yaşamı tehdit edici, kronik seyirli otoimmün bir hastalıktır.
Pemfigusun dünyadaki yıllık insidansı bölgeden bölgeye farklılık göstermekte ve milyonda 0,76-9,3 arasında değişmektedir.' Ülkemizde geneli kapsayan bir veri olmamakla birlikte Akdeniz bölgesindeki yıllık insidansı milyonda 2,4 olarak saptanmıştır.2 Pemfigusun etyopatogenezi ilk kez 1964 yılında

Yazıșma Adresi/Address for Correspondence: Dr. Gülșen Tükenmez Demirci, Bașkent Üniversitesi Istanbul Sağlık Uygulama ve Araștırma Merkezi Hastaneși, Dermatoloji Kliniği, Istanbul, Türkiye E-posta: gulsentukenmez@yahoo.com Geliş Tarihi/Received: 30.10.2010 Kabul Tarihi/Accepted: 07.11.2010

Türkderm-Deri Hastalıkları ve Frengi Arșivi Dergisi, Galenos Yayınevi tarafından basılmıștır.

Turkderm-Archives of the Turkish Dermatology and Venerology, published by Galenos Publishing. 
Beutner ile Jordanın intersellüler antijene karşı oluşmuş antikorları göstermesi ile aydınlanmaya başlamıştır. Ancak bu otoimmün olayı tetikleyen uyaranların ne olduğu konusu halen tartışılmaktadır. Illk olarak 1969 yılında Degos ve arkadaşları, bazı ilaçların pemfigusa neden olduğunu ortaya koyarak dış etkenlerin hastalığı tetikleyebileceğini göstermiştir. ${ }^{3}$ Bugün kabul edilen görüş pemfigusun genetik yatkınlığa ek olarak, bazı ilaçlar, ultraviyole ışınları, termal hasar, iyonize radyasyon vb. gibi fiziksel etkenler, neoplaziler, infeksiyonlar, kontakt duyarlandrıcılar, emosyonel stres, nutrisyonel faktörler gibi endojen ve eksojen nedenlerin karmaşık bir etkileşimi sonucu ortaya çıtığıdır. ${ }^{4}$ Bu nedenle biz de kliniğimizde tedavi ettiğimiz pemfiguslu hastaları, doğup büyüdükleri yerler, meslek grupları, eğitim düzeyi, gebelik sayısı, stresli yaşam olayları, diyet, sigara ve alkol alışkanlığı açısından sorgulayarak olası risk faktörlerini araştırdık.

\section{Gereç ve Yöntem}

Çalışma 1998-2004 yılları arasında deri ve zührevi hastalıklar kliniğinde, poliklinik başvuru sırasına göre, klinik, histopatolojik ve direkt immünfloresan inceleme ile pemfigus tanısı konan 18 yaş üstü 42 hasta ve polikliniğe başvurarak ekzema, yüzeyel mantar infeksiyonları, akne veya piyodermi tanıları alan, 18 yaş üstü 42 kişilik kontrol grubu ile yapıldı. Hastalar çalışma hakkında bilgilendirilerek sözlü onayları alındıktan sonra çalışmaya dahil edildi. Hastalara, doğup büyüdükleri yerler, medeni halleri, eğitim düzeyleri, meslekleri, gebelik sayısı, hastalık başlangıcından 1 yıl öncesine kadar boşanma, ölüm, iflas, aile bireylerinden ayrılma, kronik hastalık gibi stresli yaşam olaylarından bir veya birkaçına maruz kalma, sigara, alkol, çay, kahve, acı ve baharatlı yiyecek yeme alışkanlıkları tek bir hekim tarafından sözel olarak soruldu ve cevapları anket formlarına dolduruldu.
Hastaların doğup büyüdükleri yerler 7 coğrafik bölge sınırları içerisinde değerlendirildi. Eğitim düzeyleri açısından hastalar, okuma yazma bilmeyen, ilk, orta ve yüksek öğretim mezunu olarak gruplandı. Çalışılan iş kolları tarım, hayvancılık, sanayi ve diğerleri olarak ayrıldı. Işsiz olup olmadıkları soruldu. Sigara ve alkol kullanımı hastalık başlamadan öncesinde aktif içen, içip bırakan ve hiç içmeyenler olarak değerlendirildi. Sigara içiyorsa ne kadar süre ve günde kaç adet içtiği, bırakmış ise kaç yıldır içmediği, alkol kullanım miktarını belirlemek üzere alkollü içki türü, günde kaç kadeh içtiği ve kullanım süresi sorgulandı. Çay ve kahve alışkanlığı sorgulanarak, günlük kullanım miktarı, 1-3 bardak, 4-6 bardak ve 6 bardaktan fazla olmak üzere sınıflandı. Kadın hastalar gebelik sayısına göre, hiç gebe kalmamış, 1-3, 46 ve altıdan fazla sayıda gebe kalmış olanlar şeklinde gruplandı.

Çalışmada elde edilen bulgular değerlendirilirken, istatistiksel analizler için SPSS (Statistical Package for Social Sciences) for Windows 10.0 programı kullanıldı. Çalışma verileri değerlendirilirken tanımlayıcı istatistiksel metodların (Ortalama, Standart sapma) yanısıra niteliksel verilerin karşılaştırılmasında Ki-Kare testi kullanıldı. Sonuçlar \%95'lik güven aralığında, anlamlılık p<0,05 düzeyinde değerlendirildi (Tablo-1 ve Tablo-2) .

\section{Bulgular}

Çalışmaya yaş ortalaması 47.88 olan, 15'i erkek (\%35,7), 27'si kadın $(\% 64,3) 42$ hasta alındı. Hastaların 37'si pemfigus vulgaris $(\% 88,1)$, 2'si pemfigus vejetans $(\% 4,8), 2$ 'si pemfigus eritematozus $(\% 4,8), 1^{\prime} \mathrm{i}$ pemfigus foliaseus $(\% 2,4)$ tanısı almışlardı. Kontrol grubu ise yaş ortalaması 41.36 olan 18'i erkek, 24'ü kadın toplam 42 olgudan oluşmuştu. Kontrol ve çalışma grupları arasında yaş ortalaması ve cinsiyet dağılımı bakımından anlamlı bir farklılık yoktu $(p>0,05)$.

\section{Tablo 1. Gruplara göre doğup büyüdükler yer, meslek, gebelik ve menopoz durumu karşılaştırması}

\begin{tabular}{|c|c|c|c|c|c|c|}
\hline & & \multicolumn{2}{|c|}{ Hasta Grubu } & \multicolumn{2}{|c|}{ Kontrol Grubu } & $\mathrm{p}$ \\
\hline \multirow{4}{*}{$\begin{array}{l}\text { Doğup } \\
\text { büyüdükleri } \\
\text { yer }\end{array}$} & Marmara & 3 & 7,1 & 3 & 7,1 & \multirow{4}{*}{0,148} \\
\hline & Karadeniz & 11 & 26,2 & 15 & 35,7 & \\
\hline & G.Doğu Anadolu & 4 & 9,5 & 3 & 7,1 & \\
\hline & Akdeniz & - & - & 2 & 4,8 & \\
\hline \multirow{4}{*}{ Meslek } & Tarım & 8 & 19,0 & 2 & 4,8 & \multirow{4}{*}{$0,002^{* *}$} \\
\hline & Hayvancilık & 7 & 16,7 & - & - & \\
\hline & Endüstri & 1 & 2,4 & - & - & \\
\hline & Çalışmıyor & 16 & 38,1 & 17 & 40,5 & \\
\hline \multirow{2}{*}{ Gebelik } & 4-6 gebelik & 6 & 22,2 & 14 & 48,3 & \multirow{2}{*}{$0,014^{*}$} \\
\hline & 6 dan fazla gebelik & 16 & 59,3 & 5 & 17,2 & \\
\hline \multirow{2}{*}{ Menopoz } & Evet & 8 & 29,6 & 11 & 37,9 & \multirow{2}{*}{0,512} \\
\hline & Hayır & 19 & 70,4 & 18 & 62,1 & \\
\hline
\end{tabular}


Eğitim düzeyleri sorulduğunda hastaların 5 'inin hiç okula gitmediği $(\% 11,9), 4$ 'ünün okuma yazma bilmediği $(\% 9,5), 31$ 'inin ilk veya ortaokul mezunu olduğu $(\% 73,8), 2$ 'sinin lise mezunu $(\% 4,8)$ olduğu öğrenildi. Kontrol grubundaki hastaların ise 4'ünün okuma yazma bilmediği $(\% 9,5), 22$ 'sinin $(\% 52,4)$ ilk veya ortaokul mezunu olduğu, 16'sının lise mezunu $(\% 38,1)$ olduğu öğrenildi.

Hastaların, doğup büyüdükleri yerler sorulduğunda, 21'inin Doğu Anadolu (\%50), 11'inin Karadeniz (\%26,2), 4'ünün Güneydoğu Anadolu (\%9,5), 3'ünün Marmara $(\% 7,1)$, 3'ünün İç Anadolu bölgesinden $(\% 7,1)$ olduğu öğrenildi. Kontrol grubunda ise hastaların $11^{\prime} i$ Doğu Anadolu (\%26,2), 15'i Karadeniz (\%35,7), 3’ü Güneydoğu Anadolu (\%7,1), 3’ü Marmara $(\% 7,1)$, 8'i iç Anadolu (\%19) bölgesin-

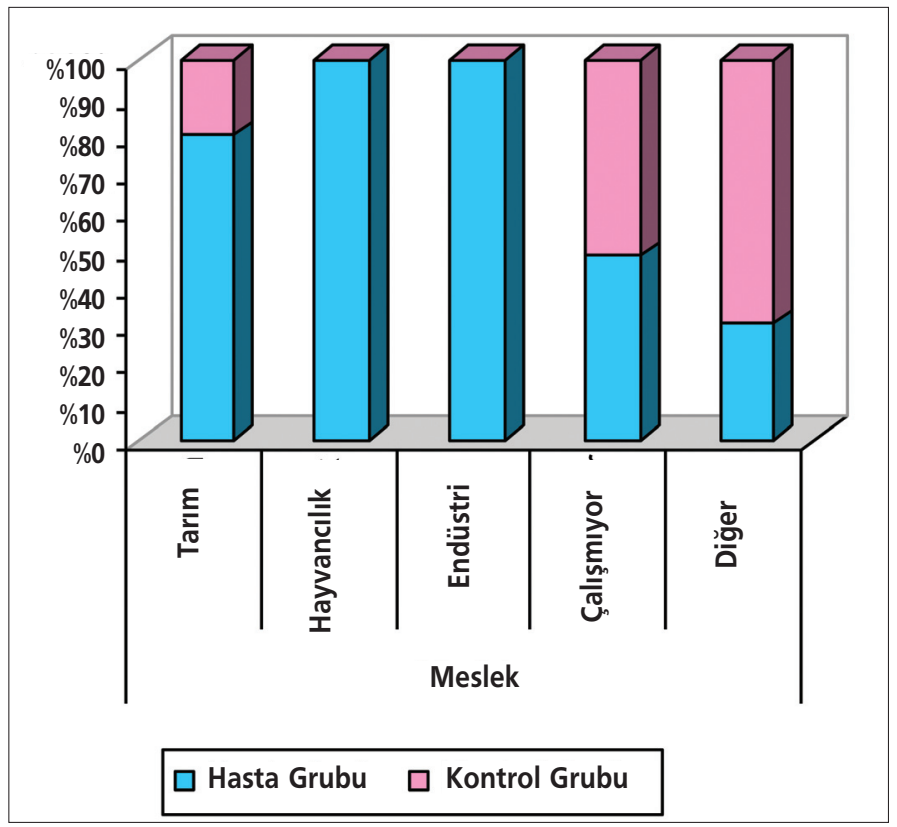

Şekil 1. Mesleklere göre grupların dağılımı

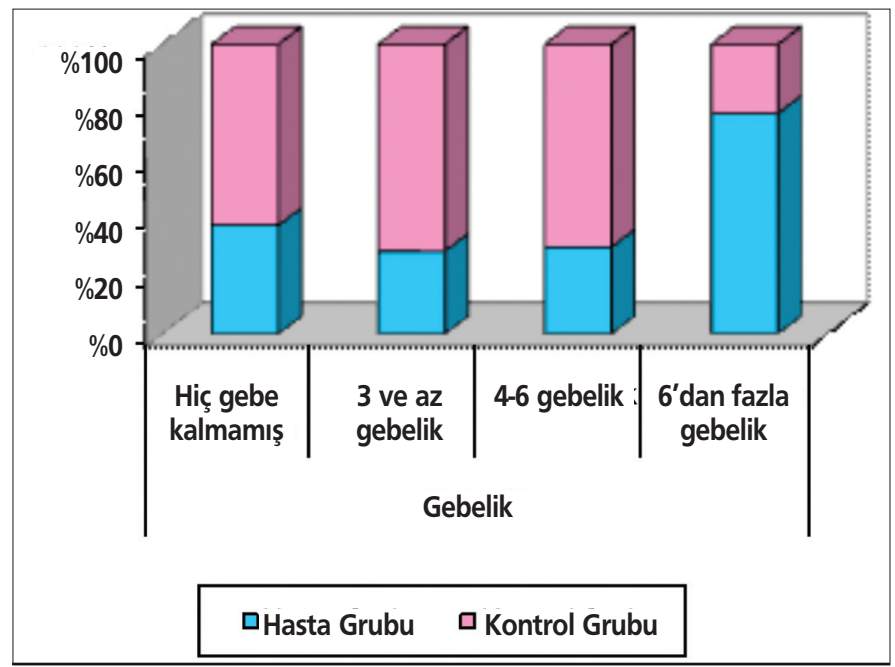

Şekil 2. Gebeliğe göre grupların dağılımı

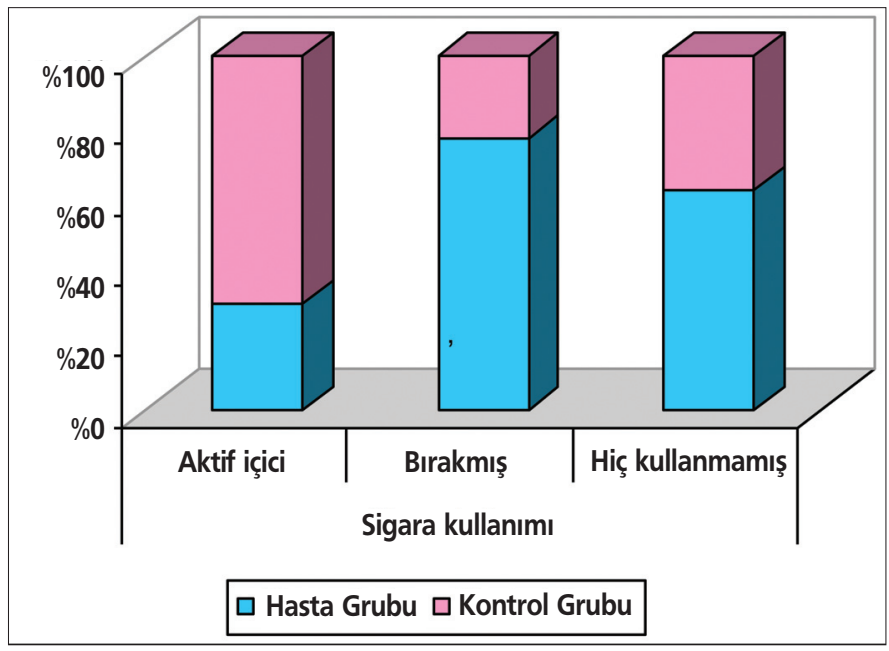

Şekil 3. Sigara kullanımına göre grupların dağılımı

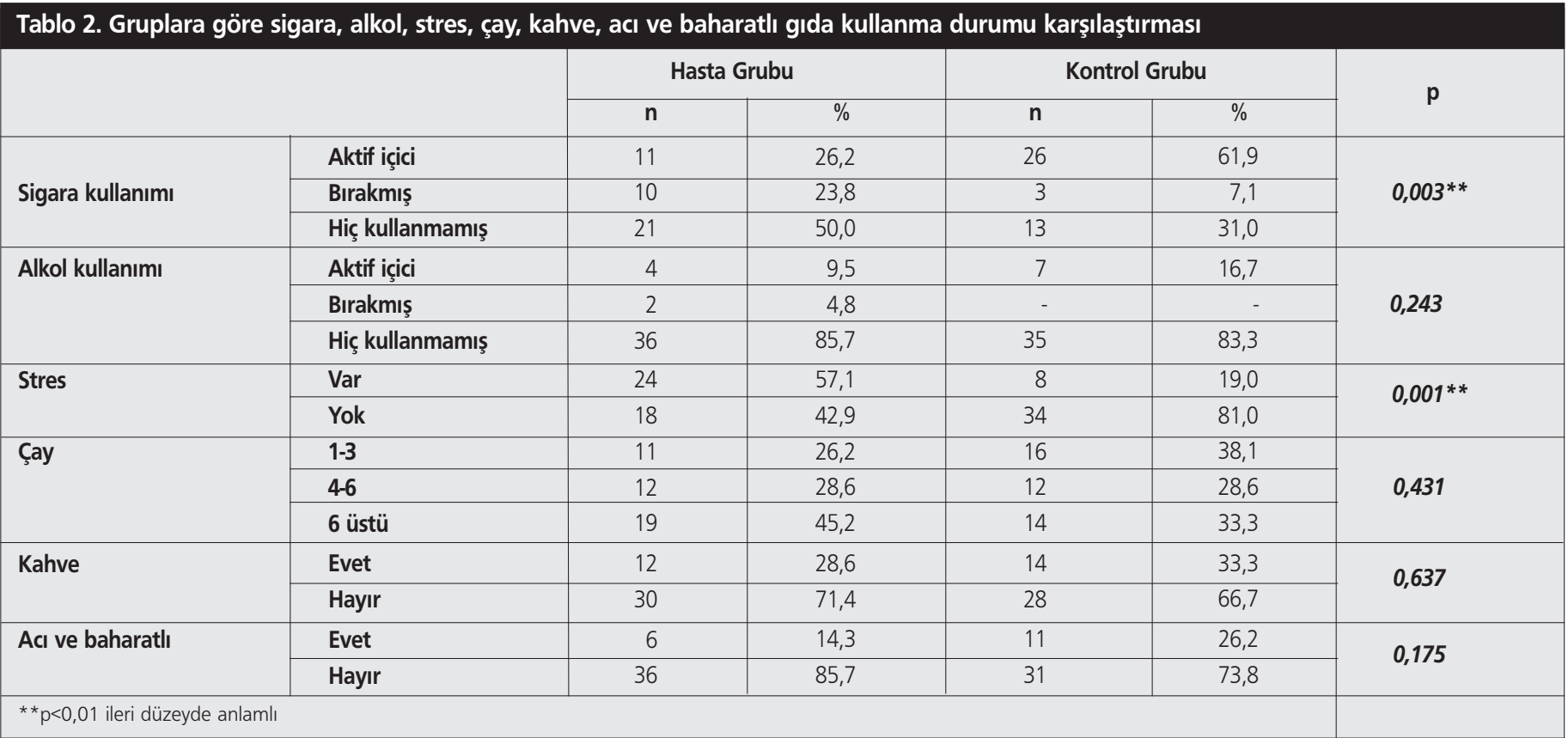




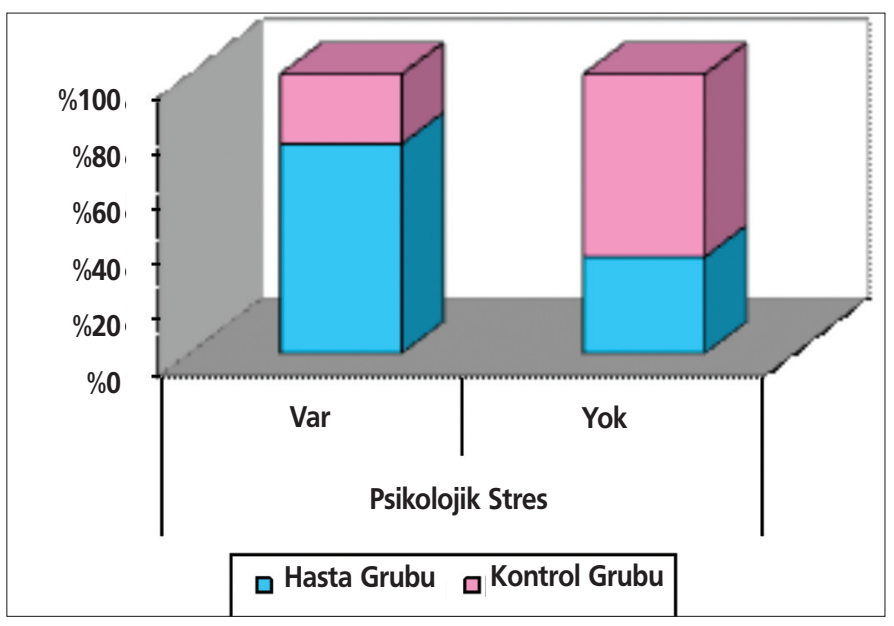

\section{Şekil 4. Psikolojik stres varlığına göre grupların dağılımı}

dendi. Kontrol gurubuna oranla hastaların daha büyük bölümü Doğu Anadolu bölgesinden olmasına rağmen istatistiksel olarak iki grup arasında anlamlı bir fark gözlenmedi.

Hasta grubundaki olguların 16 'sı çalışmıyorken (\% 38,1), 8'inin tarım ile uğraştığı (\%19), 7'sinin hayvancılık yaptığı $(\% 16,7)$, 1'inin endüstri alanında $(\% 2,4)$, 10'unun $(\% 23,8)$ ise diğer meslek gruplarında çalıştığı görüldü. Kontrol grubunda hayvancılıkla uğraşan kimse bulunmazken, 2'sinin tarım ile uğraştığı $(\% 4,8), 17$ 'sinin çalışmadığı $(\% 40,5)$, 23'ünün diğer meslek gruplarında çalıştığı gözlendi (\%54,8) (Şekil-1). Hasta grubundaki 27 kadın olgudan 16'sı 6'dan fazla sayıda gebe kalmışken (\% 59,3), kontrol grubundaki 24 kadın olgunun 14'ünün 4 ila 6 kez gebe kaldığı öğrenildi $(\% 48,3)$ (Şekil- 2).

Menopoza göre gruplar arasında istatistiksel olarak anlamlı bir farklılık bulunmadı $(p>0,05)$. Her iki grupta da olguların çoğunluğunun menopoza girmediği görüldü.

Sigara kullanımına göre gruplar arasında istatistiksel olarak ileri düzeyde anlamlı farklılık bulundu $(p<0,01)$. Hasta grubundaki tüm olguların $11^{\prime} i(\% 26,2)$ aktif içici iken, kontrol grubunda 26 kişi $(\%$ 61,9) aktif içiciydi. Cinsiyete göre sigara kullanımında da istatistiksel olarak ileri düzeyde anlamlı farklılık saptandı $(p<0,01)$. Hasta grubunda erkek olguların \%46,7'si aktif içici, \%40'ı bırakmış iken, kadın olguların \%70,4'ünün hiç sigara kullanmadığı görüldü (Şekil-3).

Alkol kullanımına göre gruplar arasında istatistiksel olarak anlamlı bir farklılık bulunmadı $(p>0,05)$. Her iki gruptaki olguların çoğunluğunun hiç alkol kullanmadığı görüldü.

Çay ve kahve içme alışkanlıklarına göre gruplar arasında istatistiksel olarak anlamlı bir farklılık bulunmadı $(p>0,05)$.

Acı ve baharatlı yemek yeme alışkanlığına göre gruplar arasında istatistiksel olarak anlamlı bir farklılık bulunmadı $(p>0,05)$. Her iki gruptaki olguların çoğunluğunun acı ve baharatlı yemek yemediği görüldü. Hasta grubundaki olgularda psikolojik stres varlığının, kontrol grubu olgularına göre anlamlı düzeyde yüksek olduğu görüldü $(p<0,01)$ (Şekil-4).

\section{Tartışma}

Bugüne kadar pemfigus etyopatogenezinde genetik yatkınlığa ek olarak çok çeşitli risk faktörleri araştırılmıştır. Pemfigusun dünya üzerindeki insidensini araştıran bir çalışmada enlem derecesi arttıkça insidensin azaldığı, enlem derecesi azaldıkça insidensin arttığı gözlenmiştir. Endemik pemfigusun gelişmemiş bölgelerde ortaya çıkması viral etyoloji ve kötü hiyjen şartlarının patogenezde önemli bir yere sahip olduğunu düşündürmüştür. Ayrıca belirli bölgelerde kapalı yaşam şartlarına bağlı belirli genetik özelliklerin hastalığı kolaylaştırdığı da düşünülebilir. Bu nedenle araştırmamızda pemfiguslu hastaların ülkemizin hangi coğrafi bölgesinden geldikleri konusuna önem verilmiştir. Hastaların doğum yeri yanında anne ve babasının doğup büyüdükleri bölgeler de ayrıca sorgulanmıştır. Hastaların \%50'sinde 21/42 memleket Doğu Anadolu bölgesi olarak saptanmıştır. illere göre hasta dağılımında sırasıyla Kars (altı), Ağrı (dört), Bingöl (üç), Sivas (iki), Erzincan (iki), ve Bitlis (iki), Van (bir), Erzurum (bir) kaydedilmiştir. Bu bölgede akrabalar veya aynı köyden olan insanlar arasında evliliğin sık olması, hastaların ortak genetik özellikler taşıma olasılığını düşündürmektedir. Ayrıca bu bölgede sosyoekonomik şartlar da ortalamanın altındadır. Doğu Anadolu bölgesinde pemfigusa daha sık rastlansa da bu fark istatistiksel olarak anlamlı bulunmamıştır; daha geniş hasta serilerinde yapılacak olan araştırmalar ile güvenilir sonuçlara ulaşılacağını düşünmekteyiz.

Hastalarımızın \%95'i 8 yıldan az eğitim almışlardı ve kontrol grubu ile karşılaştııılığında aradaki fark istatistiksel olarak anlamlı bulundu. $(p<0,05)$ Meslek grupları açısından yapılan değerlendirmede pemfiguslu hastaların sıklıkla tarım ve hayvancılıkla geçindiği tespit edildi. Daha önce Brenner ve arkadaşlarının yaptığı bir çalışmada bahçe işleriyle ilgili materyallere ve pestisitlere temasın pemfigusu tetikleyebileceği öne sürülmüştür. ${ }^{6}$

Araştırma grubumuzda sadece 1 hastanın mesleği nedeniyle metal buharına maruz kaldığı öğrenildi. Kontrol grubunda ise hiçbir hasta böyle bir işle uğraşmamaktaydı. Metallerin immün sistemi etkilediğini gösteren bazı durumlar bilinmektedir. Kronik inflamatuvar hastalıkların metallere temas ile uyarılabileceği ve palmoplantar püstülozlu hastaların bir kısmında metal allerjisinin rol oynadığı bildirilmiştir.? Bulgaristan'da yapılan bir çalışmada 74 pemfiguslu hastanın 12'sinin metal endüstrisinde çalıştığı saptanmıştır. Pemfigus ile metal endüstrisi arasındaki ilişkiler yeni ve araştırılması gereken bir konu gibi gözükmektedir.

Gebeliğin pemfigusu alevlendirdiği veya ortaya çıkmasını kolaylaştırdığı bilinmektedir. Literatürde gebelik sırasında pemfigus nedeniyle tedavi edilen 49 olgu bildirilmiştir. ${ }^{9}$ Çalışmamızda kontrol grubu ile yapılan karşılaştırma sonucunda hastaların pemfigus ortaya çıkmadan önce daha çok sayıda gebelik geçirdiği saptandı $(p<0,05)$. Bir hastada pemfigusun gebeliğin sekizinci haftasında ortaya çıktığı gözlendi. Brenner ve arkadaşları pemfiguslu hastalarda hastalık ortaya çıkmadan önce geçirilen gebelik sayısının yüksek olduğunu bildirmişlerdir. Bu verilerin aksine Valikhani ve Bastuni araştırmalarında gebelik sayısında bir artış saptamamış, ancak pemfiguslu hastalarda oral kontraseptif kullanımının daha sık olduğunu bildirmişlerdir., ${ }^{60,11}$ Bizım hastalarımızın çok sayıda gebelik geçirmiş olmaları çoğunun Doğu ve Güneydoğu Anadolu bölgelerinden geliyor olmalarına ve o bölgelerde Türkiye geneline göre gebelik oranı ve doğum hızının yüksek olmasına bağlı olabilir. ${ }^{12}$ Pemfigusun bazı otoimmün hastalıklarda olduğu gibi infertilite ile ilişkisi olduğu da ileri sürülmüştür. ${ }^{13}$ Bu nedenle pemfiguslu gebe sayısı oldukça azdır ve bu konuyla ilgili yeterli araştırma yapılamamıştır. ${ }^{14}$ Östrojenin pemfigusun ortaya çıkmasında rol oynadığı öne sürülmüş, ancak gebelikte progesteron hakimiyeti olduğu halde hangi mekanizma ile gebeliğin pemfigusu alevlendirdiği de henüz açıklanamamıştır. İmmün sistem ile sinir sistemi arasındaki etkileşimler daha önce gösterilmiştir. Otoimmün hastalıkların çoğunda psikolojik stresin rol oynadığı bilinmektedir. ${ }^{15}$ On üç pemfiguslu hasta üzerinde yapılan bir çalışmada 12 hastanın hastalık ortaya çıkmadan önceki bir yıl içinde stresli yaşam olaylarına 
maruz kaldığı gösterilmiştir. ${ }^{16}$ Bizim çalışmamızda kontrol grubu ile yapılan karşılaştırma sonucunda bazı stresli olayların hasta grubunda istastistiksel olarak anlamlı ölçüde $(p<0,01)$ yüksek oranda yaşandığı tespit edildi.

Hastaların beslenme alışkanlıklarını araştırmaya yönelik, çay, kahve, acı ve baharatlı yiyecek yeme alışkanlıkları sorgulandığında, her iki grupta da çayın fazla miktarda tüketildiği, acı ve baharatlı yiyeceklerin az oranda yenildiği görüldü. Diyet alışkanlığı ile hastalık arasında bir ilişki kurulamadı. Brenner ve arkadaşları genetik yatkınlığı olan bireylerde fenol ve tiyol grubu içeren gıda ve ilaçların pemfigusu tetikleyebileceğini göstermiştir. ${ }^{17}$ Felliciani ve arkadaşları tannik asitin invitro akantolizi indüklediğini göstererek, tannik asit içeren gıdaların pemfigusu tetikleyebileceğini öne sürmüştür..$^{18}$ Çay, kahve, acı ve baharatlı gıdalar, tiyol, izotiosiyanat, tannik asit ve sülfür içermektedir. ancak hastalarımızda bu gıdaların kontrol grubuna göre daha fazla tüketildiğine ait bir veri elde edilmemiştir.

Sigara içmenin pemfigus üzerindeki etkisi ile ilgili farklı mekanizmalar öne sürülmüştür. Mehta ve Martin sigarayı bıraktıktan sonra hastalığın kötüleştiği, tekrar başladıktan sonra ise bir hafta içinde iyileşme gösterdiği bir pemfigus olgusu bildirmiştir. ${ }^{19}$ Insan keratinositleri geniş bir asetilkolin ağına sahiptir ve asetilkolini sentezleme, depolama, salma ve yıkma işlemlerini yapabilir. Keratinosit membranlarında asetilkolin için nikotinik ve muskarinik reseptörler bulunur. Nikotinin nikotinik asetilkolin reseptörlerine bağlanması ile iyon kanalları açılır ve hücreler arasındaki adhezyon gücü artar, akantoliz durur ve keratinositler ilerleyerek erozyonları onarır. Grando ve Mark pemfigusta kolinerjik sistemin bozulduğunu öne sürmüştür. Bu yazarlar nikotinin etkisini, pemfigus antikorlarının keratinositlere tutunmasını engelleyerek ve bu antikorların akantolitik etkisini düzenleyen hücreler arası sinyal yolaklarını bloke ederek gösterdiğini savunmuştur. ${ }^{20}$ Valikhani ve arkadaşları ise sigara içme oranınının pemfiguslu hastalarda kontrol grubuna göre düşük olduğunu tespit etmiş ve sigara içen pemfiguslu hastaların daha kısa sürede remisyona girdiklerini bildirmiştir. ${ }^{21}$ Sigara içerisinde bulunan nikotinin akantolizi engelleyici ve iyileşmeyi hızlandırıcı etkisi araştırmacıları epidermisteki kolinerjik ileti sisteminin işleyişine incelemeye yöneltmiştir. Illk kez Nyuginen ve arkadaşları insan alfa 9 asetil kolin reseptörünün keratinosit adhezyonunda rol oynadığını ve bu reseptöre karşı antikorlar ile akantolizin gerçekleştiğini göstermiş̧ir.22 Insan epidermisinde nöronal olmayan kolinerjik sistem üzerindeki çalışmalar son yıllarda hız kazanmış, nikotinik ve muskarinik reseptörlerin bir çok alt tipi ile hücreler arası adhezyonda rol alan biyokimyasal ileti arasındaki ilişkiler pemfigus patogenezinde yeni ufuklar açmıştı. ${ }^{23,24,25}$ Chernyyavsky ve arkadaşları M1 muskarinik ve alfa 7 nikotinik reseptörlerin eşleşmesi ile pemfigustaki akantolizi inhibe ederek, hastalığın tedavisinde kolinomimetik ajanların etkili olacağını öne sürmüştür. ${ }^{26}$

Günümüzde pemfigus vulgaris, herpes simpleks labialis, dermatitis herpetiformis ve akne rozasenin sigara içenlerde daha az rastlandığı kabul edilmektedir. ${ }^{27}$ Sigara içilmesi, immünglobulin düzeylerinde, yardımcı T hücresi/baskılayıc T hücresi oranında, lenfosit transformasyonu ve doğal öldürücü T hücrelerinin sitotoksik aktivitesinde azalmaya neden olmaktadır. ${ }^{28}$ Nikotinin bazı proinflamatuvar sitokinlerin üretimini etkilediği de gösterilmiştir. Nikotine kronik invivo maruziyet sonucu T hücrelerinde gelişen anerjinin immünsüpresyona neden olduğu ortaya konmuştur. Ayrıca nikotinin hipotalamo-pituiter adrenal aksı uyararak endojen glukokortikoidleri arttırması da immünsüpresyona yol açar. Bu immünsüpresyon antijenik uyarıya tolerans gelişmesini sağlamaktadır. ${ }^{29}$ Nikotinin topikal veya sistemik kullanımının pemfigusta kullanılan diğer immünosüpresif ajanların kullanım intiyacını bu etki mekanizması ile azaltabileceği öne sürülmüştür. ${ }^{20}$
Pemfigus hastalarında sigara içme oranı özellikle kadın hastalarda daha belirgin olmak üzere düşük bulunmuştur. Sigara içen kadınlarda osteoporoz ve erken menopoz gibi bazı östrojene bağımlı fizyolojik olayların daha erken ortaya çıktığı bilinmektedir. ${ }^{23}$ Etyolojisinde östrojenin sorumlu tutulduğu endometriyal kanser ve miyomlar sigara içen bayanlarda daha az görülmektedir. Sigara içmenin bu antiöstrojenik etkinliğinin pemfigus patogenezinde koruyucu rol oynaması da muhtemel gibi gözükmektedir. ${ }^{30}$

\section{Sonuç}

Pemfiguslu hastalarda risk faktörlerini araştırmak amacıyla yapılan bu çalışma ile tarım ve hayvancılık iş kollarında çalışmanın, düşük eğitim düzeyinin, çok sayıda gebelik geçirmenin ve sigara içmemenin pemfigus gelişimi ile ilişkili olabileceği sonucuna varılmıştır.

Bu bulgular daha önce yapılan epidemiyolojik araştırmalar ile uyumlu bulunmuştur. Ancak hasta sayımızın az olması nedeniyle daha çok sayıda hasta üzerinde ve çok merkezli yönetilen araştırmalar ile bu bulguların desteklenmesi gerekmektedir.

\section{Kaynaklar}

1. Uzun S: Pemfigus. Dermatoloji. Ed.Tüzün Y, Gürer MA, Serdaroğlu S, Oğuz O, Aksungur VL: 3. baskı. İstanbul, Nobel Tıp Kitapevleri, 2008;807-832

2. Uzun S, Durdu M, Akman A, Gunasti S, Uslular C, Memisoglu HR, et al: Pemphigus in the Mediteranean region of Turkey: A study of 148 cases. Int J Dermatol 2006;45:523-8.

3. Degos $R$, Touraine $R$, Belaich $S$, Reva J: Pemphigus in a patient treated with penicillamine for Wilson's disease. Bull Soc Fr Dermatol Syphiligr 1969; 76:751-3

4. Ruocco E, Aurilia A, Ruocco V: Precautions and suggestions for pemphigus patients.Dermatology 2001;203:201-7.

5. Meyer N, Misery L: Geoepidemiologic considerations of auto-immune pemphigus. Autoimmun Rew 2010;9:A379-82.

6. Brenner S, Tur E, Shapiro J, D'avino M, Ruocco E, Tsankov N, et al: Pemphigus vulgaris: environmental factors. Occupational, behavioral, medical, and qualitative food frequency questionnaire. Int J Dermatol 2001;40:562-9.

7. Nakamura K, Imakado S, Takiawa M: Exacerbation of pustulosis palmaris et plantaris after topical application of metals accompanied by elevated levels of leukotriene B4 in pustules. J Am Acad Dermatol 2000;42:1021-5.

8. Tsankov N, Vassileva S, Kamarashev J, Kazandjieva J, Kuzeva V: Epidemiology of pemphigus in Sofia, Bulgaria. A 16 year retrospective study. Int J Dermatol 2000;39:104-8

9. Kardos M, Levine D, Gürcan HM, Ahmed RA. Pemphigus vulgaris in pregnancy: analysis of current data on the management and outcomes. Obstet Gynecol Surv 2009;64:739-49.

10. Valikhani M, Kavusi S, Chams-Davatchi C, Daneshpazhooh M, Barzegari M, Ghiasi $\mathrm{M}$, et al: Pemphigus and associated environmental factors: a casecontrol study. Clin Exp Dermatol 2007;32:256-60.

11. Bastuji-Garin S, Turki H, Mokhtar I, Nouira R, Fazaa B, Jomaa B, et al: Possible relation of Tunisian pemphigus with traditional cosmetics: a multicenter case- control study. Am J Epidemiol 2002; 155:249-56.

12. Özgür EM: Türkiye'de Doğurganlık hızının mekansal dağıımı. Coğrafi Bilimler Dergisi 2004;2:1-12

13. Fainaru O, Mashicah R, Kupferminc M, Shenhov M, Pauzner D, Lessing JB: Pemphigus in pregnancy: a case report and review of literature. Human Repro 2000;15:1195-7.

14. Cremniter D, Baudin M, Roujeau JC, Prost C: Stressfull life events as potential triggers of pemphigus. Arch Dermatol 1998;134:1486-7.

15. Morell-Dubois S, Carpentier O, Cottencin O, Queyrel V, Hachulla E, Hatron PY, et al. Delaporte Stressful Life Events and Pemphigus Dermatology 2008;216:104-8.

16. Brenner S, Srebrnik A, Goldberg I: Pemphigus can be induced by topical phenol as well as by foods and drugs that contain phenols or thiols. J Cosmet Dermatol.2003;2:161-5.

17. Feliciani C, Ruocco E, Zampetti A, Toto P, Amerio P, Tulli A, et al. Tannic acid induces in vitro acantholysis of keratinocytes via IL-1alpha and TNF-alpha. Int J İmmunopatol Dermatol 2007;20:289-99.

18. Brenner S, Mashiah J, Tamir E, Goldberg I, Wohl Y: PEMPHIGUS: an acronym for a disease with multiple etiologies. Skinmed 2003;2:163-7. 
19. Mentha JN, Martin AG: A case of pemphigus vulgaris improved by cigarette smoking. Arch Dermatol 2000;136:15-7

20. Grando SA, Dahl MV: Nicotine and pemphigus. Arch Dermatol 2000;136:1269.

21. Valikhani M, Kavusi S, Chams-Davatchi C, Hallaji Z, Esmaili N, Ghandi N, et al. Impact of smoking on pemphigus. Int J Dermatol. 2008;47:567-70.

22. Nguyen VT, Ndoye A, Grando SA: Novel human alpha9 acetylcholine receptor regulating keratinocyte adhesion is targeted by Pemphigus vulgaris autoimmunity. Am J Patol 2000;157:1377-91.

23. Lindstrom J. Autoimmune diseases involving nicotinic receptors. J Neurobiol 2002;53:656-65.

24. Grando SA: Cholinergic control of epidermal cohesion. Exp Dermatol 2006;15:265-82.

25. Kurzen $\mathrm{H}$. The extraneuronal cholinergic system of the skin. Basic facts and clinical relevance. Hautarzt 2004;55:453-9.
26. Chernyavsky Al, Arredondo J, Piser T, Karlsson E, Grando SA: Differential coupling of M1 muscarinic and alpha7 nicotinic receptors to inhibition of pemphigus acantholysis. J Biol Chem. 2008;283:3401-8.

27. Thomsen S, Sørensen L: Smoking and skin disease. Skin Therapy Lett. 2010;15:4-7.

28. Sullivan TP, Elgart GW, Kirsner RS: Pemphigus and smoking. Int I Dermatol 2002; 41:521-31.

29. Geng Y, Savage SM, Razanai-Boroujerdi S, Sopori ML: Effects of nicotine on the immune response. II. Chronic nicotine treatment induces T cell anergy. J Immunol 1996;156:2384-90.

30. Wilkins JN, Carlson HE, Van Vunakis H, Hill MA, Gritz E, Jarvik ME: Nicotine from cigarette smoking increases circulating levels of cortisol, growth hormone, and prolactin in male chronic smokers. Psychopharmacology 1982;78:305-8. 